\title{
FUS/ATF1 Fusion Gene
}

National Cancer Institute

\section{Source}

National Cancer Institute. FUS/ATF1 Fusion Gene. NCI Thesaurus. Code C99277.

A fusion gene that results from a chromosomal translocation $t(12 ; 16)(q 13 ; p 11)$ which fuses the first 5 exons of the FUS gene on the 5 ' side of exon 5 of the ATF1 gene. This rearrangement is associated with angiomatoid fibrous histiocytoma. 